\title{
A DECISION SUPPORT TOOL FOR LANDFILL METHANE GENERATION AND GAS COLLECTION
}

\section{Harriet Emkes $^{1}$, Frédéric Coulon ${ }^{1}$ and Stuart Wagland ${ }^{1 *}$}

${ }^{1}$ School of Energy, Environment and Agrifood, Cranfield University, Cranfield, Bedfordshire, MK43 0AL, United Kingdom.

\begin{abstract}
This study presents a decision support tool (DST) to enhance methane generation at individual landfill sites. To date there is no such tool available to provide landfill decision makers with clear and simplified information to evaluate biochemical processes within a landfill site, to assess performance of gas production and to identify potential remedies to any issues. The current lack in understanding stems from the complexity of the landfill waste degradation process. Two scoring sets for landfill gas production performance are calculated with the tool: (1) methane output score which measures the deviation of the actual methane output rate at each site which the prediction generated by the first order decay model LandGEM; and (2) landfill gas indicators' score, which measures the deviation of the landfill gas indicators from their ideal ranges for optimal methane generation conditions. Landfill gas indicators include moisture content, temperature, alkalinity, $\mathrm{pH}, \mathrm{BOD}, \mathrm{COD}, \mathrm{BOD} / \mathrm{COD}$ ratio, ammonia, chloride, iron and zinc. A total landfill gas indicator score is provided using multicriteria analysis to calculate the sum of weighted scores for each indicator. The weights for each indicator are calculated using an analytical hierarchical process. The tool is
\end{abstract}


tested against five real scenarios for landfill sites in UK with a range of good, average and poor landfill methane generation over a one year period (2012). An interpretation of the results is given for each scenario and recommendations are highlighted for methane output rate enhancement. Results demonstrate how the tool can help landfill managers and operators to enhance their understanding of methane generation at a sitespecific level, track landfill methane generation over time, compare and rank sites, and identify problems areas within a landfill site.

Key Words: Multi-criteria analysis, landfill assessment, landfill gas indicators, methane generation, waste management. 


\section{Introduction}

The improvement of the generation of methane for gas collection and sale from landfills is hampered by a general lack in understanding of landfill processes at the field-scale (Cho et al., 2012). Difficulties in understanding derive from the heterogeneous nature of landfill waste, lack of access to the waste once deposited and the interpretation of a wide variety of landfill parameters. The causes of landfill gas production fluctuations in the field continue to be largely unknown. Therefore, there is a need for decision support tool (DST) that can integrate a wide range of data to understand how well a landfill site is performing in terms of methane output rate and what can be done to improve it. Landfill operators are concerned with the cost of monitoring sites and the revenues generated from the energy produced from gas collection. Enhancing methane output increases the landfill operator's revenues and offsets the cost of gas extraction system implementation, maintenance and operation. Electricity and heat produced from landfill gas can be sold for revenue in addition to income from government incentives such as the feed in tariff, renewable obligation certificates and the renewable heat incentive. Strickland (2010) argues that a steady profit can be achieved in a relatively short period of time, however costs for all factors involved vary widely among sites and therefore estimates are not quoted here. However, there is a clear business case for improving landfill methane generation at existing sites.

There is currently no DST used specifically for the assessment of landfill methane generation. The majority of tools for landfill sites focus on environmental risk management objectives in accordance with environmental regulations (Laner et al., 2012). Models are also available to predict landfill gas output such as LandGEM and GasSim (Golder Associates, 2013; US EPA, 2005) but these do not provide guidance as 
to what is problematic in the landfill or what can be done to increase gas production for collection. However, there is a well-established literature base on multi-criteria analysis (MCA) which can be applied to landfill methane generation to assimilate a wide base of landfill gas production knowledge into a decision support tool.

A DST provides a robust, consistent, transparent and reproducible method for the decision making process (Sorvari and Seppälä, 2010). MCA is essential for the use of a DST in a landfill situation due to the wide range of processes and parameters involved. It is a widely used and tested method in modern policy decision making such as deciding between which waste management technologies to use (Dodgson et al., 2009). The aim of this research is to develop and present a DST to enhance methane generation within individual landfill sites. The objectives are to: (1) provide landfill decision makers with clear and simplified information on the state of a landfill site in terms of landfill gas production for gas collection with reference to target values; (2) develop a tool that highlights what problems exist within a landfill site; (3) provide recommendations as to what can be done to enhance methane generation; (4) provide supporting information about the tool to the user to understand its limitations and the assumptions made and (5) provide the framework for a tool which can be improved over time as new data becomes available.

This paper presents a unique DST to assess landfill methane generation on a sitespecific basis with two scores. The first score assesses the methane output produced over time compared to predictive model values. The second provides a breakdown of landfill gas indicators to assess the viability of the landfill environment to produce methane. Parameters include $\mathrm{pH}$, ammonia and moisture content. This is achieved by comparing actual values for key indicators to previously recorded data. The user is then 
able to prioritise areas of management which can enhance landfill methane generation for gas collection. The tool also provides suggestions for possible remedial actions for each indicator where issues have been identified.

\section{A DST for landfill methane generation}

\subsection{Interface}

The tool was developed in the Microsoft Excel 2010 to ensure it is accessible to the widest range of audience. The tool includes a series of worksheets in which the user can enter input data, run simulation and see the results and possible actions to landfill gas problems, gain insights into the calculations and underlying data. The user is able, at a basic level, to enter data for a specific site, view results and remedies. At a more advanced level further tabs are available to understand how the scores are calculated and certain model parameters can be altered.

\subsection{Method for decision support tool development}

\subsubsection{Landfill process theory}

A general understanding of landfill methane generation processes is necessary to develop a DST. The processes that take place in landfills are widely described in literature through laboratory, field and theoretical experimentation (Mata-Alvarez, 2003; Themelis and Ulloa, 2007; Christensen and Kjeldsen, 1995). It is generally accepted that the organic waste fraction goes through a series of phases of degradation including hydrolysis, acetogenesis, methanogenesis and oxidation (Barlaz et al 1990). A landfill site is expected to have turned to methanogenic conditions within 2 years and 
therefore the ideal range of most leachate indicators changes after this time in the DST (World Bank - ESMAP, 2004).

These phases simultaneously produce variations in the environment within the landfill and produce changes in leachate, waste and gas composition. Leachate characteristics, or indicators, include $\mathrm{pH}$, alkalinity, chemical oxygen demand (COD) and biochemical oxygen demand (BOD). These indicators can be used to estimate the expected rate of methane generation within a landfill. Due to the anaerobic nature of landfill sites, parameter values are very similar across a range of landfill sizes in Europe (Kjeldsen et al., 2002) and can therefore be used in a DST to measure landfill methane generation.

\subsubsection{Landfill gas models}

The move to achieve the complete landfill gas (LFG) recovery for energy production from UK landfill sites has led to some waste management companies using models as a resource and risk assessment tool for landfill gas estimation (Kamalan et al., 2011). The models use various input parameters such as assumed half-life of waste decay and waste composition which determine the amount of carbon in the waste mass that can be transformed into methane and carbon dioxide (Kamalan et al., 2011). Other important factors such as moisture content, climate and temperature influence these parameters and affect the prediction of LFG production. When these factors are poorly defined, the results of the models are significantly uncertain (Amini et al. 2011; Kamalan et al., 2011).

First-order kinetics are often used in methane production models (GasSim, LandGEM, TNO, Afvalzorg and EPTR) are presented by Kalaman et al. (2011) and Thompson et 
al. (2009). The three key factors identified for methane generation models for a landfill site are (Thompson et al., 2009):

1. the amount of waste disposed since commissioning

2. the degradable organic fraction

3. the decay rate (of each fraction and as a whole).

As many old landfills (pre-2005) do not hold records of waste quality or quantity the composition of the waste is not always known and therefore estimations and extrapolations are necessary in many cases. More recently, the IPCC guidelines (2006) established a method that can be applied to all countries/regions and provides default values (e.g. regional generation rates), estimates and calculation methods to compensate for the lack of historical data (IPCC, 2006). However these estimates introduced higher uncertainty in the final results and sites with poor management data have the highest uncertainties in their calculations. In addition the overall rate of LFG emission can be influenced by operational interventions such as waste compaction, leachate recirculation or aerobic landfilling and theoretically these factors should also be taken into consideration when modelling generation. Thus the main criticism of methane prediction models is their lack of accuracy and validation and therefore simple models are preferred (Bogner and Matthews, 2003; Thompson et al., 2009; Oonk, 20).

In this study, the LandGEM waste model (USEPA, 2005) was chosen as it requires a small amount of data input but provides an estimation of the evolution of cumulative landfill gas emissions over time. This provides benefits over simpler models such as EPRTR model (Ademe, 2003) which provides only a total value of gas emissions which cannot be used in a DST to assess methane generation at yearly intervals. The rate of 
methane output in terms of cubic meters per hour provides the closest current indicator of landfill stability and landfill gas optimisation (Mata-Alvarez, 2003).

was selected to estimate rate of emissions from decomposed landfill waste (Equation 1; Reinhart et al., 2005).

$\mathbf{Q}_{\mathrm{CH}_{4}}=\sum_{\mathrm{i}=1}^{\mathrm{n}} \sum_{\mathrm{j}=0.1}^{1} \mathbf{k L}_{0}\left(\frac{\mathrm{M}_{\mathrm{i}}}{10}\right) \mathrm{e}^{-\mathrm{k} \mathrm{t}_{\mathrm{ij}}}$

\section{(Equation 1)}

where $\mathrm{Q}_{\mathrm{CH} 4}=$ annual methane generation in the year of the calculation $\left(\mathrm{m}^{3} / \mathrm{year}\right) ; \mathrm{i}=1$ year time increment; $n=($ year of the calculation $)$ - (initial year of waste acceptance $) ; j=$

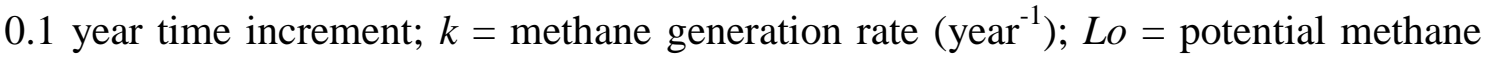
generation capacity, meter cube per metric ton $\left(\mathrm{m}^{3} / \mathrm{t}^{-1}\right)$. This factor depends on rate of decay and composition of waste; $\mathrm{Mi}=$ mass of waste accepted in the $\mathrm{i}^{\text {th }}$ year $(\mathrm{t})$; $\mathrm{tij}=$ age of the $\mathrm{j}^{\text {th }}$ section of waste mass Mi accepted in the $\mathrm{i}^{\text {th }}$ year (decimal years, e.g. 3.2 years) (USEPA, 2005).

The $k$ and $\mathrm{L}_{0}$ factors use Clean Air Act (CAA) default values for the measurement of the parameters (USEPA, 2005). Methane generation rate $(k)$ has default value $0.04 \mathrm{yr}^{-1}$ for areas receiving $635 \mathrm{~mm}$ or more annual rainfall precipitation and $0.02 \mathrm{yr}^{-1}$ for areas receiving less than $635 \mathrm{~mm}$ and $0.30 \mathrm{yr}^{-1}$ for wet landfills (USEPA, 2008; Amini et al. 2011). Potential methane generating capacity $\left(\mathrm{L}_{0}\right)$, depend on the land fill site, waste composition and ultimate methane yield of each component have default values ranging from 6 to $270 \mathrm{~m}^{3} / \mathrm{t}^{-1}$ (EPA, 2005).

\subsubsection{Calculating the landfill site scores}

As a quantitative method, the target value approach was chosen to meet the aim and objectives of the landfill methane generation DST. However, the literature reviewed highlighted the need for the tool user to be aware of the limitations of using a target- 
value approach including the need to recognise site-specific issues at landfill sites. The landfill methane generation is assessed by two scores (Figure 1). Green, yellow and red lights are used to indicate good, average and poor scores. The first score assesses the actual methane output rate for each site against what rate is predicted for that site using the LandGEM model (US EPA, 2005).

\section{>>> Insert Figure $1<<<<<<$}

The second score assesses the landfill environment by using the MCA method used by Krajnc and Glaviĉ (2005a; 2005b) to score each landfill gas indicator against the ideal range for that indicator for methane generation. In this way, the methane output score is the primary source of assessment for each landfill site and the landfill gas indicator score provides a secondary insight into why a landfill may have good, average or poor methane generation. Each indicator is given a score which, if red, suggests that it is negatively influencing methane generation.

\subsubsection{Methane output score}

The methane output score is calculated by comparing the predicted methane output rate to the actual methane output rate for a given site. The methane output is predicted using the LandGEM model for the ideal methane output. The score is expressed as the percentage deviation from the predicted value:

$M_{x, t}=\left(B_{A}-B_{I}\right) / B_{I}$ 
where $M$ is the methane output score for site ' $x$ ' at time ' $t$ ', ' $B_{A}$ ' the actual methane output $\left(\mathrm{m}^{3} / \mathrm{yr}\right)$ and ' $\mathrm{B}_{\mathrm{I}}$ ' the ideal value for methane output $\left(\mathrm{m}^{3} / \mathrm{yr}\right)$. Therefore, a score of $0 \%$ represents the actual methane output being equivalent to predicted output.

The methane output score is given a red, yellow or green light to highlight good, average or poor methane output rate. A green light indicates a score higher than $30 \%$ which is determined by defining the error margin of the LandGEM model to be $30 \%$ either side of the actual score (Oonk, 2010). A yellow light represents a score of -30$30 \%$ whilst a red light represents a score below $-30 \%$. The boundaries over which red, yellow and green lights are given can be changed in further versions of the model.

\subsubsection{Methane output prediction}

The landfill gas model "LandGEM" is used to predict LFG production or potential methane generation capacity for up to five sites. The methane calculation worksheet is used from the original LandGEM model. The calculation is based on user input of age, waste acceptance and potential methane generation capacity $\left(\mathrm{L}_{0}\right)$. The default parameters for a conventional landfill (inventory) used are as follows: decay rate constant: $\mathrm{k}=0.04$ and potential methane generation capacity: $\mathrm{L}_{0}=100 \mathrm{~m}^{3} / \mathrm{Mg}$.

However, LandGEM assumes all waste accepted into the landfill site is MSW which is not necessarily the case. For example, a waste composition with higher cellulose content has a higher $\mathrm{L}_{0}$ value and therefore produces a higher methane output. A guide is provided as background for a range of $\mathrm{L}_{0}$ values used in the LandGEM model based on wet bioreactor, conventional landfills and CAA regulatory values (USEPA, 2005). Therefore the potential methane generation capacity value can be altered by the user depending on the composition of waste if known. 


\subsubsection{Landfill gas indicator score - multi-criteria decision analysis}

The second element of the DST is to calculate a score for the landfill gas indicators. MCA is used to combine the scores of the landfill gas indicators. In order to achieve the aim of an understandable tool, the method used by (Krajnc and Glavič, 2005a and 2005b) was followed (Figure 2).

\section{>>>> Insert Figure $2<<<<<$}

This method provides a mathematically transparent composite index score by combining key measurable leachate, waste and biogas parameters and comparing those to ideal values. The parameters are assumed to be independent, as no field-scale data was available to conduct sensitivity analysis on. The scenario testing performed did not provide sufficient data to apply the Spearman's rank correlation test. Also, the literature reviewed did not highlight a sensitivity analysis to quantify the effect of one parameter on another. Meima et al. (2008) found that water content had a greater influence on microbial growth including temperature and $\mathrm{pH}$, but did not quantify the effects. Other parameters that are dependent on each other are $\mathrm{pH}$ and heavy metals in which the solubility of heavy metals into landfill leachate increases in acidic conditions (Kjeldsen et al., 2002). However, the effect of inhibitors to methane generation such as methane generation can be controlled by the control of the more influential parameters of moisture content, alkalinity and $\mathrm{pH}$. 


\subsubsection{Indicator selection and optimal ranges}

There are many indicators of landfill methane generation and therefore many that could be used in a DST. The indicators for this DST were selected according to their influence on methane generation and the availability of measured data. Table 1 shows which indicators have been selected for the DST and which have not been included. Table 1 also provides guideline values of moisture content and temperature for optimal methane generation. While the data is sourced from 1996, more recent data which can apply to a range of landfill sites was not located. This reflects the difficulty in providing data which generalises all landfill sites and hence the need to make the user aware of the limitations of the decision support tool. Table 1 further provides upper and lower boundary levels for a range of parameters in landfill leachate observed in Germany (which has the same temperate climate as the UK) from 1983 and 1988. Whilst more recent data has been published (Robinson, 2007) this only applies to very large landfill sites (5 to $10 \mathrm{Mm}^{3}$ of void space) and therefore cannot be used in a decision support tool for a range of sites. Hence, further work on finding the optimal ranges of the indicators of methane generation within landfill sites would improve the accuracy of the decision support tool.

>>> Insert Table $1<<<<<$

\subsubsection{Calculating individual landfill gas indicator scores and normalizing the indicator values}

The landfill gas indicator score is calculated for each individual indicator initially on an unweighted basis using the following equation: $I_{N, i t}=\left(I_{A, i t}-I_{V, i}\right) /\left(I_{V, i}-I_{L, i}\right)$. Where $I_{N, i t}$ is the normalized indicator $I$ for time $\mathrm{t}$ and $I_{A}$ is the actual indicator value, 
$I_{V}$ is the average ideal value and $I_{L}$ is the lower boundary of the ideal value range. The score is normalized against the average ideal value and lower boundary of the ideal value range in order to compare and aggregate different units. The scores used to define the boundaries for the coloured light system are based on values provided in Table 1 of optimal methane generation boundaries for green values and are assigned arbitrary levels for yellow and red score.

It is important that the score is relative to the size of the boundary as a small change in one indicator could have a much larger effect than another if the boundary was smaller. The scores are given red, green and yellow light symbols within the DST which are dependent on the boundary levels for the scores set (Figure 3).

\section{>>> Insert Figure $3<<<<<$}

The boundary levels are based on the ideal value range for each indicator (Table 2). However, the model can be updated if necessary by users to alter the boundary levels as deemed necessary. As an example, for $\mathrm{pH}$ in methanogenic conditions the ideal lower and upper values are 7.5 and 9 and these values are the boundaries for the green light. The values are normalized using equation above to give scores of -1 and 1 for the lower and upper boundaries of each parameter. Hence, the average ideal value, for methanogenic $\mathrm{pH}$ this is 8.25 is assigned a score of 0 . The yellow zone encapsulates a score greater than 1 and -1 but less than 1.25 and greater than -1.25 . For the methanogenic $\mathrm{pH}$ indicator this is 7.3 - 7.5 and 9-9.2 respectively. Scores with absolute values greater than this on both positive and negative scales are given a red light. Whilst the $\mathrm{pH}$ scale differs from the other parameters being logarithmic as opposed to 
linear, the same boundaries are used as the scores are normalised by the dividing the difference between actual and optimum scores by the range of the optimum boundaries.

\section{>>> Insert Table $2<<<<<$}

\subsubsection{Calculating the total weighted landfill gas indicator score}

\subsubsection{Normalizing the indicators}

The indicators are normalized during the procedure to calculate individual landfill indicator scores.

\subsubsection{Weighting}

Each parameter is then weighted according to its influence on the required objective such as $\mathrm{pH}$ having a high influence on the goal of methane maximisation. There are many different methods of weighting parameters or indicators such as multi attribute utility theory and a linear additive model (Dodgson et al., 2009). The analytical heirachy process $[\mathrm{AHP}]$ was chosen as it provides a straightforward method of calculating the relative weights of each parameter (Krajnc and Glavič, 2005b; Krajnc and Glavič, 2005a) 
The AHP uses a linear additive model which gives a value score for an option for each criterion, multiplies this by the weight of the criteria and sums the scores together (Saaty, 1987) (Figure 4 and Table 3). The AHP varies from other linear additive models by using pairwise comparison of criteria to assign weights (Saaty, 1987; Vaidya and Kumar, 2006).

Default scores from 1-9 for each indicator are provided but can be updated by the user according to site specific information of landfill gas indicator influence on methane generation. Default values were assigned by a panel of one academic and one professional in the waste industry who operates a landfill site.

>>>Insert Figure $4<<<<<$

>>> Insert Table $3<<<<<$

\subsubsection{Combining the weighted scores}

The individual landfill gas indicator scores are multiplied by the weighting for each indicator, given an absolute value and summed to give the total weighted landfill gas indicator score for each site (equation 2)

$\sum_{i t}^{n} W_{i} \times\left|I_{N, i t}\right|$

(Equation 2)

where: $\sum_{i}^{n} W_{i}=1$ and $W_{i} \geq 0$. And where I: individual landfill gas indicator score; $\mathrm{N}$ : normalized indicator; W: weighting and T: time.

This provides a useful summary of how much the site varies from ideal values for methane generation over all indicators. The weighted scores are given an absolute value before being summed to show the total magnitude of deviation from the ideal value. 


\subsection{Landfill methane generation remedies}

After a light score (red, yellow or green) has been given to each methane output score or landfill gas indicator, the DST allows the user to view the cause and effect of an indicator having a red or yellow light and highlights potential remedies for that indicator to produce a higher methane output rate (Table 4). Literature sources of leachate data are displayed in the tool. Some remedies mentioned in the table are restricted by the lack of ability to apply them retrospectively including reducing waste density and the mixture of wastes added. The remedy most used at the field scale level to improve overall methane generation is leachate recirculation. This aspect of the DST is intended to enhance the general understanding of the effect of each indicator on methane output production and possible remedies. It is not intended as comprehensive advice on how to resolve landfill methane generation issues. Potential remedies need to be assessed on a site-specific basis.

\section{>>>Insert Table $4<<<<<$}

\section{Scenario testing}

\subsection{Scenarios}

Data from five genuine landfill sites (LFS) in UK have been used for developing the scenarios and to demonstrate how the DST can be used to assess good, average and poor landfill site gas performance and provide suggestions for improvement. Table 5 displays the landfill gas, leachate and waste parameters for each site used in the DST. Briefly, a description for each landfill site is provided hereinafter: 
- LFS1 opened in 1986 and closed in 2009. The site is considered as a wet landfill site. At its closing year, it had the highest LFG production among the five sites. Waste was mostly domestic waste.

- LFS2 opened in 1998 and is still operating. LFS2 is a relatively deep quarry where mostly compacted domestic and non-domestic wastes were buried. Compared to the four others landfill sites, LFS2 produces a high quantity of LFG with an average of $1531 \mathrm{~m}^{3} / \mathrm{hr}$ in 2009 . This production can be explained by the presence on the site of several temporary capping. Furthermore, it is a very wet site which favours the degradability of waste. Waste input has declined lately due to loss of domestic council contract in 2010/2011.

- LFS3 opened in 1992 and received mostly sludge. The site is currently being landfilled and includes a material recycling facility and a landfill gas electricity generation facility. LFS4 is less wet due to low rainfall and might have slow degradation rate. Limited data on the input capacity as well as the size of the landfill are available.

- LFS4 opened in 2005 as a non-hazardous landfill accepting a wide range of municipal waste. The most important waste inputs were domestic waste, nondomestic waste and sundry materials. The site has little permanent capping and is considered as very wet. However, the site produces the second lowest LFG production among the five landfills with an average of $308 \mathrm{~m}^{3} / \mathrm{hr}$ in 2009 . Some engineering improvements have been implemented towards the end of 2012 to rectify this, which may explain the increase in LFG production.

- LFS5 was opened in 1989 and it accepts wide range of waste. It is wet, with gas flow collection of about $300 \mathrm{~m}^{3} / \mathrm{hr}$ at $40 \%$ methane. 
Each site is analysed for landfill methane generation in one year (2012) in the scenario testing.

\section{>>> Insert Table $5<<<<<$}

\subsection{Results and Interpretation}

The DST provides a results summary with the coloured light indication system (Figure 5). The methane output and total landfill gas indicator scores are displayed along with the light assigned to each score. The process of calculating scores for each site is discussed below.

\section{>>> Insert Figure $5<<<<<$}

\subsubsection{Landfill site 1}

For LSF1, the methane output is above predicted levels and therefore it receives a green light (Table 6). A score of $44.8 \%$ shows that it is operating at $44.8 \%$ higher levels of methane output than predicted in the LandGEM model (Table 10). Therefore no action is necessary to remediate the site.

In order to understand the biochemical processes occurring within the landfill environment to achieve this score a breakdown of landfill gas indicators is also provided (Table 6). For LFS1, most indicators are operating within the accepted range for optimal methane output. For example, a moisture content of $40 \%$ gives a score of $-14.3 \%$ below the ideal average value for optimal methane output relative to the range of the ideal value for that indicator. Alkalinity is given a yellow light, which indicates that this indicator is just outside the ideal range for methane output and needs to be monitored 
(Table 2). COD and $\mathrm{pH}$ are given a red light which indicates that they are well outside the ideal range indicated in section 2.2.5.1 and action is indicated to address this issue (Mata Alvarez, 2013 and Mali Sandip et al, 2012).

In the case of LFS1, although the overall landfill score and weighted environmental indicator score has a green light, some environmental indicators display red and yellow lights which can be addressed if wanted. This is due to the fact that methane generation is a complex and dynamic process which does not require all indicators to be green to produce green light overall. The COD indicator describes the amount of chemically oxidisable material in the leachate. This could be due to a problem within the landfill in the ability to degrade material but as the BOD and BOD/COD ratio scores are green this may indicate an error in the data provided. As the $\mathrm{pH}$ is below the ideal range for a methanogenic landfill site, potential remedial action could involve the recirculation of $\mathrm{pH}$ neutral leachate to assist the microorganisms present in regulating the $\mathrm{pH}$ to produce optimal environmental conditions for methane generation (Kjeldsen et al, 2002; Mali Sandip et al, 2012).

\section{$>>>$ Insert Table $6<<<<<$}

\subsubsection{Landfill site 2}

LFS2 recorded the highest methane output score at $60.9 \%$ higher than the ideal average of $5,470,000 \mathrm{~m}^{3} / \mathrm{yr}$ calculated for that site (Table 7). Each landfill gas indicator measurement for the site was within its accepted ranges for optimal methane output. The total landfill gas indicator score of 0.2 is close to zero which indicates little deviation from the ideal average measurement. This site is therefore given green lights 
for each parameter and no further action is suggested to enhance the methane output for the site.

\section{>>> Insert Table $7<<<<<$}

\subsubsection{Landfill site 3}

LFS3 was initially described as a site with an average landfill methane generation performance. The DST corroborated this assertion and assigned a methane output score of $-7.2 \%$, which is within the average boundary. This indicated that methane output levels are currently below predicted levels and landfill gas indicators need to be monitored (Table 8). The total landfill gas indicator score was calculated at 1.1 which is marginally above the boundary for optimal methane generation. This score is pushed outside of the green light zone largely due to the deviation of alkalinity and moisture content from the ideal range (Mali Sandip et al, 2012). These indicators are also the two most highly weighted and therefore any small deviation from the ideal range of measurements will give a high indicator score. This also indicates to the importance of monitoring and potentially taking action to bring these indicators within the ideal range. The alkalinity measured at the site is $900 \mathrm{mg} / \mathrm{L}$ which is $300 \mathrm{mg} / \mathrm{L}$ greater than the ideal average value (Mali Sandip et al., 2012). The individual indicator score is calculated as 3.0 which is well above the ideal boundary score of 1.0. The score is then weighted as 0.26 to sum the total landfill gas indicator score to give a contribution of 0.6. Addressing the issue of high moisture content will improve alkalinity as the microorganisms are better able to regulate the $\mathrm{pH}$ within the landfill site (Mata-Alvarez, 2003). Saturation of a landfill site is potentially inhibiting methane generation, as 
microbial activity is decreased under saturated conditions (Christensen et al., 1996). One potential remedy for this issue is to maintain a leachate recirculation system within the landfill site, which extracts excess moisture and feeds $\mathrm{pH}$ neutral leachate back into the site (Table 4).

\section{>>> Insert Table $8<<<<<$}

\subsubsection{Landfill site 4}

LFS 4 represents a site with a poor landfill methane generation performance. The DST has given the site a red light for the methane output score, while the total landfill gas indicator score has received a yellow light (Figure 5). Methane output is $57.7 \%$ below the LandGEM predication for the waste input for the site, which is well below the red light boundary of $-30 \%$ (Table 9). The landfill gas indicators that deviate from their ideal boundaries are: moisture content, alkalinity, $\mathrm{pH}$ and temperature. While these factors are very important for methane generation, all other indicators are within the ideal boundaries and therefore bring the total landfill gas indicator score down to a yellow light score. Action is suggested for this site to improve landfill methane generation. Methane output can be enhanced by ensuring a mixed composition of waste input in the absence of toxic agents and $\mathrm{pH}$ neutral leachate recirculation to reduce moisture content, $\mathrm{pH}$ and alkalinity and enhance microbial activity (Table 4; Kjeldsen et al, 2002; Benson et al, 2007). The temperature is more difficult to improve in waste already in place but enhanced microbial activity from the aforementioned methods will produce heat and raise the temperature (Mata Alvarez, 2003). Other methods include the pre-heating of waste entering the site. 


\subsubsection{Landfill site 5}

LFS5 also has methane generation below expected levels. The DST methane output score is $-57.5 \%$ which is well below the LandGEM prediction for this site and it is given a red light (Table 10). The total landfill gas indicator score is also given a red light at 1.6 which is mainly affected by the low moisture content and alkalinity measurements at the site. Moisture content at $10 \%$ is well below the ideal boundary of $25-60 \%$ (Table 1) and as it is given a high weighting contributes an absolute score of 0.5 to the total. Alkalinity is also below the ideal boundary for a landfill in methanogenic conditions of 500-700 mg/L (Table 1; Mata Alvarez, 2003) and contributes 0.8 to the total landfill gas indicator score. Remedial action is therefore necessary for this site to improve the methane output rate, alkalinity and moisture content. The potential actions for these indicators have already been highlighted for previous sites.

\section{>>> Insert Table $10<<<<<$}

\subsection{Discussion}

The scenario testing proved that the DST can be reliably used to highlight good, average and poor performance as it produced scores for each site that were consistent with the initial scenario assessment (Figure 5). However, the use of detailed and continuous monitoring data would help to further refine and validate the model. The methane output score was over 30\% (green light) for both well performing LFS 1 and 2 and below $-30 \%$ (red light) for both poor performing LFS 4 and 5 with LFS 3 tending to 0\% (yellow light) (Figure 5). The use of a more accurate landfill gas model within the 
methane output score when developed in the future would improve the overall reliability of the DST and the scores it produces. This includes the accurate choice of potential methane capacity and degradation constant values according to what waste is emplaced in the site. The inherent problem of the DST is its reliance on accurate data input by the user, which is difficult to obtain in the waste industry due to a historic lack of data recording. However, newer landfills and newer models with better data recording practices will increase the reliability of the model.

The total landfill gas indicator scores for each site deviated above the optimal range boundary of 1.0 for sites 3-5 and remained between 0 and 1.0 for LFS 1 and 2. LFS 2 produced both the highest methane output score and total LFG indicator score which demonstrates the reliability of the DST as indicator scores within the optimal ranges should enhance methane generation. The total LFG indicator score, however, hides the deviation of individual indicators which in some cases are given a red light when the total landfill gas indicator score is given a green light (for example in LFS1, Table 6). This is due to the fact that landfill processes are complex and dynamic and while some indicators have a high influence on the methane output rate, others do not. This is accounted for in the weighting mechanism of the tool. For example, optimal moisture content allows for the transportation of nutrients, microorganisms and intermediate products for enhanced biodegradation of waste to produce methane. The microorganisms necessary for the biodegradation of waste also need moisture to degrade organic substrates at each stage of the process. Another important role of moisture content is to dilute biodegradation inhibitors such as sulphates and heavy metals. Hence, moisture content has an effect on all other landfill gas indicators in a facilitator role (Christensen et al., 1996). Alkalinity is also given a high weighting as it 
measures the ability of the landfill site to buffer changes in $\mathrm{pH}$ caused by biodegradation (Mata-Alvarez, 2003). Conditions too acidic or basic inhibit microbial activity. The BOD/COD ratio measures the amount of biodegradable substrate still available for degradation and is dependent upon moisture content and alkalinity. Temperature is important to facilitate waste degradation but is given a lower weighting as it does not tend to vary significantly between landfill sites within similar climates (Robinson, 2007). Hence, each landfill gas indicator is dependent upon other indicators. The scenario testing showed that the parameters chosen for the DST only make a significant impact on the total landfill gas indicator score if they are weighted highly such as moisture content and alkalinity. Parameters such as heavy metal concentrations and temperature had a low impact on the overall score but are useful in terms of creating an overall picture of the state of the landfill site. Additional parameters could be added to the DST such as microbial population and the nutrient ratio within the site which would add further understanding to the methane generation capacity of a site (Mc Donald et al, 2009; Nayak et al, 2009). However this would add further complexity to the DST and these data are not readily available from landfill operators currently. The weightings of the parameters therefore have a significant influence on the total landfill gas indicator score. For future application and refinement of the DST, it is suggested that an extended panel of experts and industry professionals should be consulted to improve the weightings produced in this model.

\subsection{Cautionary Notes}

The DST provides a framework for the assessment of landfill methane generation. It can be used to inform decision makers of the evolutionary stage of the landfill site, to track 
landfill methane generation over time, and to compare and rank a set of landfill sites. It also has the ability to identify specific problems within a landfill site for methane generation, and provides suggestions for potential remedial action. It has been designed to allow the user to adjust the settings due to the heterogeneous nature of landfill sites. For example, the methane potential in the landfill gas model can be adjusted to reflect specific site waste inputs. Also, the weightings of the landfill gas indicators can be altered to reflect landfill operator professional knowledge of which indicator affects landfill gas generation more than others at one site. Therefore, caution must be taken to note that with different model settings, the results are not comparable and recommendations for remediation are not necessarily supported by the authors. Several limitations are highlighted below which the user should consider when reviewing the tool results. Conservative estimates must be used in order to not overestimate methane generation.

\subsubsection{Research limitations}

- The DST is based values taken from literature which need to be updated over time as new data becomes available to reflect modern landfill processes.

- The landfill gas model used in the DST, as with all landfill gas models currently available, is subject to an aforementioned wide error margin which needs to be taken into consideration when analysing the results.

- Landfill gas indicators ideal values are based on data from landfill sites in Germany in the 1980s, which may not be representative of past and future landfill sites in different geographic locations. 
- No formal sensitivity analysis has been performed to test for interactions among the landfill gas indicators to test how much one influences another due to a lack of field-scale data available for testing whilst existing influences are present and are mentioned previously.

- The weighting of landfill gas indicators for the DST is based on a small panel of one academic and one professional which could be expanded to include more experts with additional types of expertise.

\subsubsection{Tool limitations}

- Limitations in data quantity or quality reduces the reliability and increases the error of the decision support tool, and additional data collected over time will improve the tool.

- A user changing the model settings without sound technical basis may decrease the quality and applicability of the model results. Excel cells that should not be altered by users have been locked to minimise this.

- Average leachate, waste and gas measurements among cells with data are assumed to be representative of the entire landfill site.

- Atypical waste input increases the tools inaccuracy, as the landfill gas predications are based on typical inputs.

- The ideal value ranges for landfill gas indicators are taken from typical values at acetogenic and methanogenic sites. Therefore, an assumption is made that these ranges translate to optimal methane generation conditions.

- Landfill leachate is assumed to develop from acetogenic to methanogenic conditions within 2 years (World Bank - ESMAP, 2004). 
- Landfills are assumed to have not reached an aerobic stage and are less than 40 years old.

\section{Conclusion}

The results of the DST scenario testing described in this paper show how the tool can be easily used by managers and operators of landfill sites. If the user considers that any tool or model is underpinned by a set of simplified assumptions, and therefore is aware of its limitations, it could be used to understand and improve landfill methane generation. Landfill gas production is a complex and dynamic process which provides a wide ranging and complex set of data to landfill site operators. No previously available tool integrates these datasets into a simple and clear set of scores for the landfill operator to base its decision on. The literature reviewed highlighted that not only was this the case, but that it is possible to adopt well-established multi-criteria techniques and apply them to a landfill site to provide these scores. The tool selects which indicators are most important to landfill gas production by professional and academic experts to provide relevant and scientifically-based information. While this may introduce bias into the tool as opinions on which indicators are more influential than others may vary, the tool allows for the user to calculate its own weights. The tool is economically beneficial for landfill operators as it can be used to enhance profitable methane generation. The tool provides a methane output score which measures the actual methane output rate against the prediction given by the LandGEM model for the waste it has accepted. This acts as an indication of overall performance. A set of landfill gas indicator scores are also provided, which enables the decision maker to observe landfill conditions to give a good, average or poor methane output score. Each indicator 
is measured against a dataset of ideal values at both the methanogenic and acetogenic stages of landfill evolution based on literature values. The most important indicators for methane generation are moisture content and alkalinity. The weighted scores are then summed on an absolute basis. A set of lights for the scores indicate whether the parameter is performing above, at or below expected levels and whether remedial action is necessary. This also increases bias in the tool, as the boundary level for each light is subjectively set. However, the tool is designed as a framework for which the user can alter the boundary levels for site-specific cases. A set of suggestions for remedial action for each parameter is provided in the tool to provide the decision maker with possible remedies to issues in methane generation.

The DST provides a useful framework for the assessment of landfill methane generation which can be updated over time as new indicator weightings, ideal values, landfill gas models and remedial methods become apparent.

Further work needed to improve the DST would involve creating a more recent and detailed set of ideal values for methane generation parameters which to use in the tool to compare landfill site measurements against. This would involve testing a wide range of landfill sites for leachate, gas and waste parameters at each evolutionary stage of a landfill. Additional field-scale data would also allow testing of the sensitivity of individual indicators in the DST which is important for assessing the accuracy of the tool. Also, an improved landfill gas model to test the methane output rate against would give a high accuracy to the tool. On a wider scale, more detailed measurement and reporting of landfill parameters over smaller time periods by landfill operators would enable a wider selection of landfill gas indicators to be analysed to improve the accuracy of the tool. 


\section{ACKNOWLEDGMENTS}

The project was funded by Viridor Ltd and the Engineering and Physical Sciences Research Council [EPSRC]. The authors are grateful for the advice in study design and methods provided by Viridor Ltd.

\section{REFERENCES}

Ademe 2003. Outil de calcul des émissions dans l'air de CH4, CO2, SOx, NOx issues des centres de stockage de déchets ménagers et assimilés, Ademe, France. available at: https://www.declarationpollution.ecologie.gouv.fr/gerep/download/Annexe_2_Outi 1_de_calcul_ADEME_des_emissions_dans_lair_CH4_CO2_NOX_SO.pdf. (accessed 28/08/2013).

Baccini, P., 1989. The landfill - reactor and final storage, Lecture Notes in Earth Sciences., 20th ed., Springer Verlag, Berlin, Germany.

Bana e Costa, C. A., Ensslin, L., Cornêa, É C. Vansnick, J. 1999. Decision Support Systems in action: Integrated application in a multicriteria decision aid process, Euro. J. Oper. Res., 113, 315-335.

Bardos, P., Nathanail, J., Pope, B. 2002. General principles for remedial approach selection., Land Contam. Reclam. 10, 137-160.

Barlaz, M.A., Ham, R.K., Schaefer, D.M., 1990. Methane production from municipal refuse: A review of enhancement techniques and microbial dynamics. Crit. Rev. Env.. Contr. 19, 557-584. 
Barlaz, M. A., Rooker, A. P., Kjeldsen, P., Gabr, M. A., Borden, R. C. 2002, Critical evaluation of factors required to terminate the postclosure monitoring period at solid waste landfills. Environ Sci. Technol. 36, 3457-3464.

Barlaz, M. A., Schaefer, D. M., Ham, R. K. 1989. Mass balance analysis of decomposed refuse in laboratory scale lysimeters. ASCE J. Environ. Eng. 115, 1088-1102.

Belton, V., Gear, T. 1983. On a short-coming of Saaty's method of analytic hierarchies", Omega. 11, 228-230.

Benson, C.H., Barlaz, M.A., Lane, D.T., Rawe, J.M., (2007). Practice review of five bioreactor/recirculation landfills. Waste Manage. 27 (1), 13-29.

Bogner, J., Matthews, E. 2003. Global methane emissions from landfills:New methodology and annual estimates 1980-1996. Global Biogeochem. Cy. 17, 10651088.

Bogner, J., Pipatti, R., Hashimoto, S., Diaz, C., Mareckova, K., Diaz, L., Kjeldsen, P., Monni, S., Faaij, A., Gao, Q. 2008. Mitigation of global greenhouse gas emissions from waste: conclusions and strategies from the Intergovernmental Panel on Climate Change (IPCC) Fourth Assessment Report. Working Group III (Mitigation). Waste Manage Res. 26, 11-32.

Burnley, S. J., Ellis, J. C., Flowerdew, R., Poll, A. J., Prosser, H. 2007. Assessing the composition of municipal solid waste in Wales. Resourc. Conserv,. Recylc. 49, 264-283.

Burnley, S. J. 2007. A review of municipal solid waste composition in the United Kingdom. Waste Manage. 27, 1274-1285.

CEC (2003), Council Decision 2003/33/EC of 19 December 2002, Establishing criteria and procedures for the acceptance of waste at landfills pursuant to Article 16 of 
and Annex II to Directive 1999/31/EC. L11/27-49, Official Journal of the European Communities.

Chen, Y., Cheng, J. J.,Creamer, K. S. 2008. Inhibition of anaerobic digestion process: A review. Bioresour. Technol. 99,4044-4064.

Cho, H. S., Moon, H. S.,Kim, J. Y. 2012. Effect of quantity and composition of waste on the prediction of annual methane potential from landfills. Bioresour. Technol. 109, 86-92.

Cho, K. T. (2003). Multicriteria decision methods: An attempt to evaluate and unify, Math. Comput. Modell., 37, 1099-1119.

Christensen, T. H., Cossu, R., Stegmann, R. 1996. Landfilling of Waste: Biogas. Chapman and Hall, London.

Christensen, T. H., Kjeldsen, P. 1995. Landfill emissions and environmental impact: An introduction., Christensen, T. H., Cossu, R. and Stegmann, R. (eds.), in: Sardinia 1995, Fifth International Landfill Symposium, Proceedings. Vol. 3, CISA, Cagliari, Italy, .

Contreras, F., Hanaki, K., Aramaki, T., Connors, S. 2008. Application of analytical hierarchy process to analyze stakeholders preferences for municipal solid waste management plans, Boston, USA. Resourc. Conserv,. Recylc. 52, 979-991.

Cossu, R., Lai, T., Piovesan, E. 2007. Proposal of a methodology for assessing the final storage quality of a landfill. Sardinia 2007 - 11th International Waste Management and Landfill Symposium. S. Margherita di Pula, Cagliari, Italy, CISA., .

Department for Environment, Food and Rural Affairs (Defra) 2007. Waste Strategy for England, , HMSO, London. 
Department for Environment, Food and Rural Affairs (Defra) 2013. Waste and Recycling Key Facts and Figures, available at:

<http://www.defra.gov.uk/environment/waste/> (accessed 11/02/13.).

Dodgson, J. S., Spackman, M., Pearman, A., Phillips, L. D. 2009. Multi-criteria analysis: a manual. , available at: http://eprints.lse.ac.uk/12761/ (accessed 13/08/2013).

Ehrig, H. J. 1988. Water and Element Balances of Landfills, in Baccini, P. (ed.) The Landfill, Springer Verlag, Berlin, Germany. 83. ed,.

Ehrig, H.J. 1983. Quality and quantity of sanitary landfill leachate. Waste Manage. Res. $1,53-68$.

Environment Agency (2003), Guidance on Monitoring of Landfill Leachate, Groundwater and Surface Water, , Environment Agency, Bristol.

Environment Agency (2004a), Guidance on the management of landfill gas. TGN 03. Environment Agency (2004b), LandSim 2.5 - Groundwater Risk Assessment Tool for Landfill Design, Environment Agency, Bristol.

Environment Agency (2010), The surrender of permits for the permanent deposit of waste. Version 1, Environment Agency, Bristol, UK.

Environment Agency (2013), Landfill Regulation, available at: http://www.environment-agency.gov.uk/business/sectors/32445.aspx (accessed 07/16).

European Commission 2003. Establishing criteria and procedures for the acceptance of waste at landfills pursuant to Article 16 of and Annex II to Directive 1999/31/EC. 11/27, Official Journal of the European Communities L. 
European Environment Agency 2009. Annual European Community greenhouse gasinventory 1990-2007 and inventory report. European Environment Agency, Copenhagen, Denmark.

Golder Associates (2013), GasSim 2.5 Manual, available at: <http://www.gassim.co.uk/Download.html> (accessed 15/02/2013).

Gregory, R. G., Gillet, A. G. and Bradley, D. 2003. Methane emissions from landfill sites in the UK, 443/1, Land Quality Management, Nottingham.

Gregory, R. G., Revans, A. J., Hill, M. D., Meadows, M. P., Paul, L. Ferguson, C. C. 1999. A Framework to Assess the Risks to Human Health and the Environment from Landfill Gas, R\&D Technical Report P271, Environment Agency, Bristol.

Hall, D. H., Drury, D., Gronow, J. R., Pollard, S. J. T., Smith, R. 2007. Estimating pollutant removal requirements for landfills in the UK: III. Policy analysis and operational implications. Environ. Technol. 28, 25-32.

Huang, I. B., Keisler, J., Linkov, I. 2011. Multi-criteria decision analysis in environmental sciences: Ten years of applications and trends. Sci. Total Environ., 409, 3578-3594.

IPCC (2006), Guidelines for National Greenhouse Gas Inventories, International Panel on Climate Change, Task Force on National Greenhouse Gas Inventories., available at: http://www.ipcc-nggip.iges.or.jp/public/2006gl/ (accessed 27/08/2013).

Kamalan, H., Sabour, M., Shariatmadari, N. 2011. A Review on available landfill gas models. J. Environ. Sci Technol., 4, 79-92. 
Keeney, R. L., Raiffa, H. 1976. Decisions with Multiple Objectives: Preferences and Value Trade-offs. Reprinted, Cambridge University Press, 1993. ed, Wiley, New York.

Kim, H., Townsend, T. G. 2012. Wet landfill decomposition rate determination using methane yield results for excavated waste samples. Waste Manage. 32, 1427-1433.

Kjeldsen, P., Barlaz, M. A., Rooker, A. P., Baun, A., Ledin, A., Christensen, T. H. 2002. Present and long-term composition of MSW landfill leachate: a review.", Crit. Rev. Environ. Sci. Technol. 32, 297-336.

Knox, K., Braithwaite, P., Caine, M., Croft, B. 2005. Brogborough landfill test cells: the final chapter. A study of landfill completion in relation to final storage quality (FSQ) criteria. Sardinia 2005 - 10th International Waste Management and Landfill Symposium. S. Margherita di Pula, Cagliari, Italy, CISA., .

Krajnc, D., Glavič, P. 2005a. How to compare companies on relevant dimensions of sustainability. Ecol. Econ. 55, 551-563.

Krajnc, D., Glavič, P. 2005b. "A model for integrated assessment of sustainable development", Resourc. Conserv,. Recylc. 43, 189-208.

Laner, D., Crest, M., Scharff, H., Morris, J. W. F., Barlaz, M. A. 2012. A review of approaches for the long-term management of municipal solid waste landfills. Waste Manage. 32, 498-512.

Lootsma, F. A. 1992. The REMBRANDT System for Multi-criteria Decision Analysis via Pairwise Comparisons or Direct Rating. 92-05, Faculty of Technical Mathematics and Informatics, Delft University of Technology, The Netherlands. Lootsma, F. A. 1999. Multi-criteria decision analysis via ratio and difference judgment. Kluwer Academic Publishers. 
Mali Sandip, T., Khare Kanchan, C., Biradar Ashok, H. 2012. Enhancement of methane production and bio-stabilisation of municipal solid waste in anaerobic bioreactor landfill. Bioresour. Technol. 110, 10-17.

Mata-Alvarez, J. (ed.) (2003), Bio-methanization of the organic fraction of municipal solid waste. IWA Publishing, London.

McDonald, J. E., Allison, H. E., McCarthy A. J. (2009) Composition of the landfill microbial community as determined by application of domain- and group- specific 16S and 18S rRNA-targeted oligonucleotide probes. Appl. Environ.Microb. 76, $1301-1306$

Meima, J. A., Naranjo, N. M., Haarstrick, A. 2008. Sensitivity analysis and literature review of parameters controlling local biodegradation processes in municipal solid waste landfills, Waste Manage. 28, 904-918.

Morris, J. W. F., Barlaz, M. A. 2011. A performance-based system for the long-term management of municipal waste landfills, Waste Manage. 31, 649-662.

Nayak B.S., Levine A.D., Cardoso A., Harwood V.J. 2009. Microbial population dynamics in laboratory-scale solid waste bioreactors in the presenece or absence of biosolids. J. Appl. Microb. 1007, 1330-1339.

Olson, D. L., Fliedner, G., Currie, K. 1995. Comparison of the REMBRANDT system with analytic hierarchy process, Europ J. Oper. Res, 82, 522-539.

Oonk, H.(2010. Literature Review: Methane from landfills. Methods to quantify generation, oxidation and emission. OonKay, Apeldoorn.

Powrie, W., Beaven, R. P. 1998. Hydraulic conductivity of waste - current research and implications for leachate management, available at: 
http://oldweb.northampton.ac.uk/aps/env/Wasteresource/1998/NOV98/98nov22.ht $\underline{m}$ (accessed 17/12/13).

Reinhart, D. R., Faour, A. A., You, H. 2005. First-order kinetic gas generation model parameters for wet landfills. EPA-600/R-05/072, US-EPA, Washington DC, USA.

Robinson, H. D.2007. The composition of leachates from very large landfills: an international review, Com. Waste Res Manage. 8, 19-32.

Roy, B., Mousseau, V. 1996. A theoretical framework for analysing the notion of relative importance of criteria., J. Multi-Criteria Decision Analysis. 5, 145-149.

Saaty, T. 1980. The Analytical Hierarchy Process, John Wiley, New York.

Saaty, R. W. 1987. The analytic hierarchy process-what it is and how it is used", Math. Modelling. 9, 161-176.

Scharff, H., Jacobs, J., van der Sloot, H. A., van Zomeren, A. 2007. Inorganic waste landfill and final storage quality. Sardinia 2007 - 11th International Waste Management and Landfill Symposium. S. Margherita di Pula, Cagliari, Italy, CISA., .

Scharff, H., van Zomeren, A.,van der Sloot, H. A. 2011. Landfill sustainability and aftercare completion criteria., Waste Manage. Res. 29, 30-40.

Scharff, H.,Jacobs, J. 2006. Applying guidance for methane emission estimation for landfills. Waste Manage. 26, 417-429.

Sizirici, B., Tansel, B., Kumar, V. 2011. Knowledge based ranking algorithm for comparative assessment of post-closure care needs of closed landfills. Waste Manage. 31,1232-1238.

Sorvari, J., Seppälä, J. 2010. A decision support tool to prioritize risk management options for contaminated sites.Sci. Total Environ. 408, 1786-1799. 
Spokas, K., Bogner, J., Chanton, J. P., Morcet, M., Aran, C., Graff, C., Golvan, Y. M. , Hebe, I. 2006. Methane mass balance at three landfill sites: What is the efficiency of capture by gas collection systems? Waste Manage.26, 516-525.

Stegmann, R., Heyer, K., Hupe, K.,Willand, A. 2006. Deponienachsorge Handlungsoptionen, Dauer, Kosten und quantitative kriterien für die Entlassung aus der Nachsorge, Dessau, Umweltbundesamt.

Strickland, A. K. 2010. Taming of the beast: exploiting landfill gas. available at: http://www.waste-management-world.com/articles/print/volume-11/issue5/features/taming-of-the-beast-exploiting-landfill-gas.html (accessed 13/09/2013).

Tchobanoglous, G., Theisen, H., Vigil, S. A. 1993. Integrated Solid Waste Management. Engineering Principles and Management Issues. McGraw-Hill International Editions.

Themelis, N. J., Ulloa, P. A. 2007. Methane generation in landfills. Renew. Energy. 32, 1243-1257.

Thompson, S., Sawyer, J., Bonam, R., Valdivia, J. E. 2009. Building a better methane generation model: Validating models with methane recovery rates from 35 Canadian landfills. Waste Manage. 29, 2085-2091.

US EPA 2005. Landfill Gas Emissions Model v.3.02, available at: http://www.epa.gov/ttn/catc/dir1/landgem-v302.xls. (accessed 25/07/2013). USEPA 2013. Overview of Greenhouse Gases: Methane Emissions, available at: http://epa.gov/climatechange/ghgemissions/gases/ch4.html (accessed 25/11/13). Vaidya, O. S., Kumar, S. 2006. Analytic hierarchy process: An overview of applications. Europ. J. Oper. Res. 169, 1-29. 
Valencia, R., van der Zon, W., Woelders, H., Lubberding, H. J. , Gijzen, H. J. 2009. Achieving "Final Storage Quality" of municipal solid waste in pilot scale bioreactor landfills. Waste Manage 29, 78-85.

Wagland, S. T., Tyrrel, S. F., Godley, A. R., Smith, R. 2009. Test methods to aid in the evaluation of the diversion of biodegradable municipal waste (BMW) from landfill. Waste Manage. 29, 1218-1226.

Wagland, S. T., Veltre, F., Longhurst, P. J. 2012. Development of an image-based analysis method to determine the physical composition of a mixed waste material. Waste Manage 32, 245-248.

World Bank - ESMAP (2004), Handbook for the Preparation of Landfill Gas to Energy Projects in Latin America and the Caribbean, 013993 (6), Conestoga-Rovers \& Associates, Ontario. 


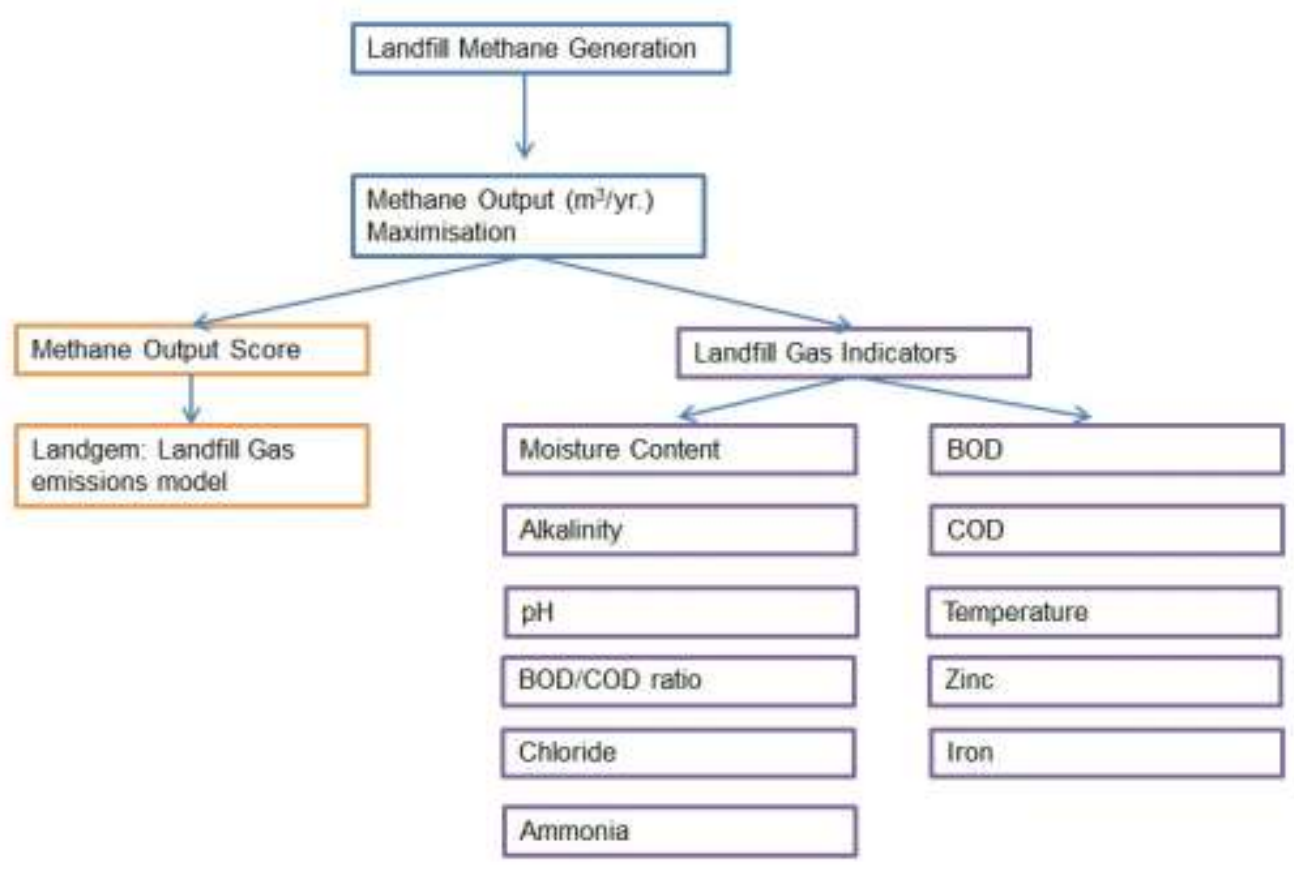

Figure 1. The landfill methane generation DST is made up of the methane output score and the landfill gas indicators score.

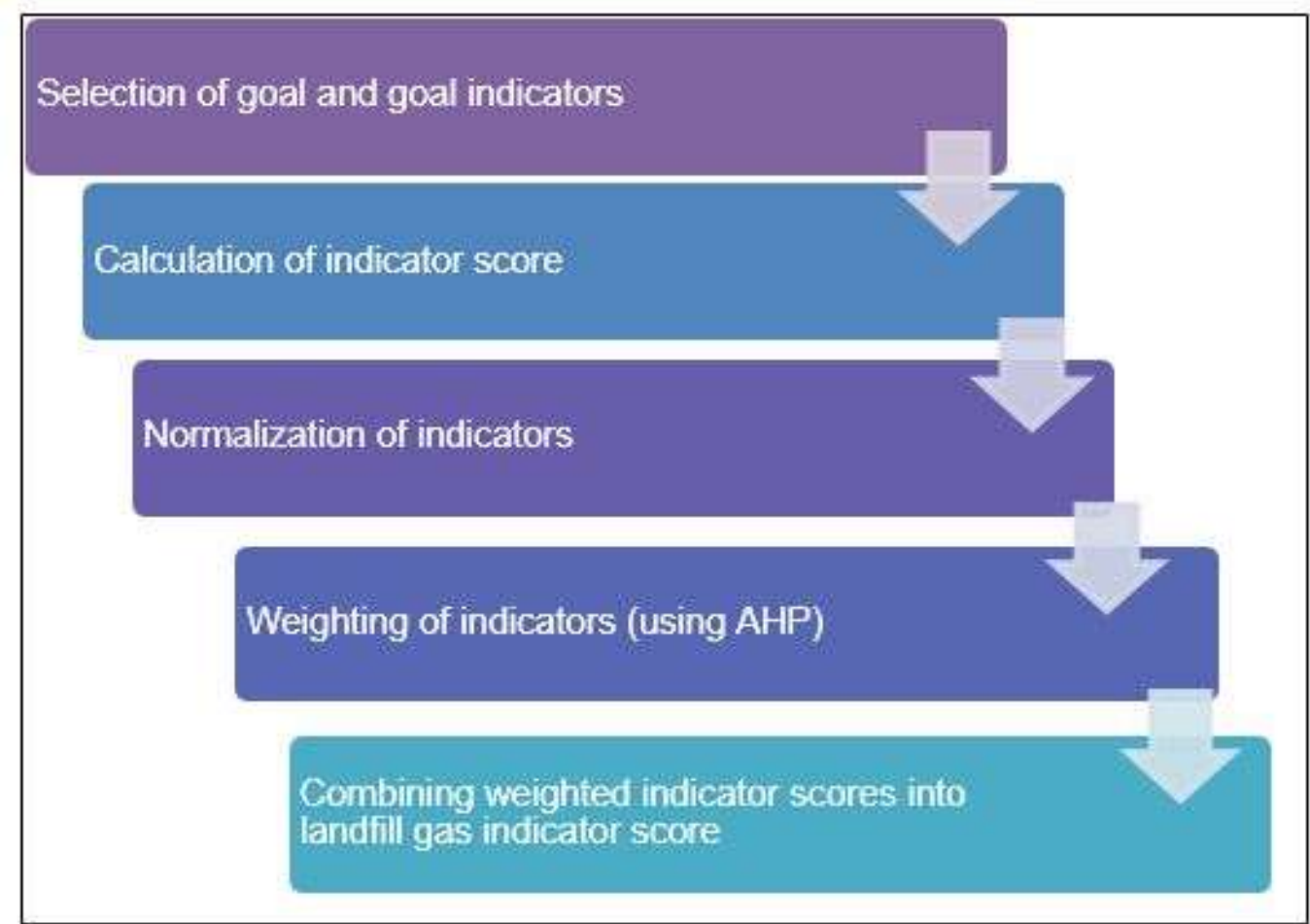

Figure 2. The procedure for calculating landfill gas indicator scores in the DST using multicriteria analysis, adapted from Krajnc and Glavic (2005a, 2005b) (AHP: Analytical Hierarchical Process). 


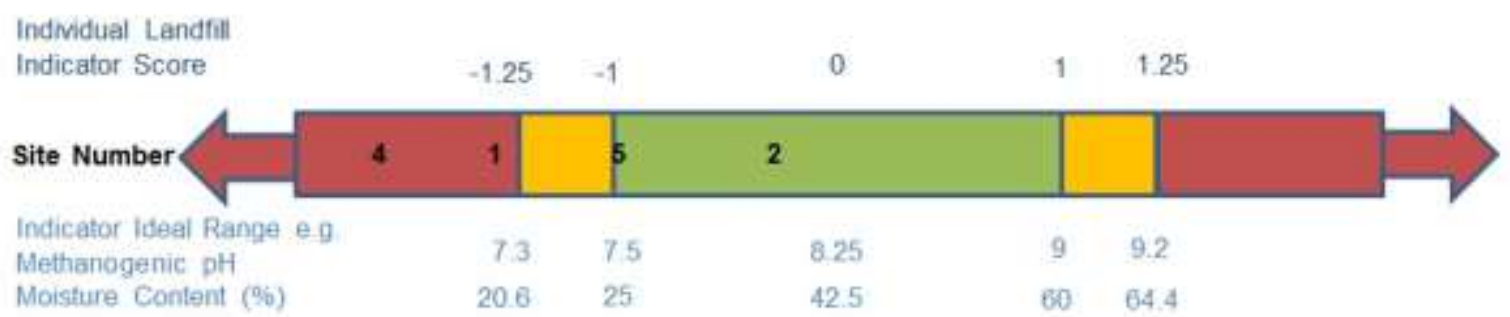

Figure 3. An example of the light system for the two landfill gas indicators. The scores reflect the proximity of the user input value for each site to the ideal average value relative to the size of the ideal range.

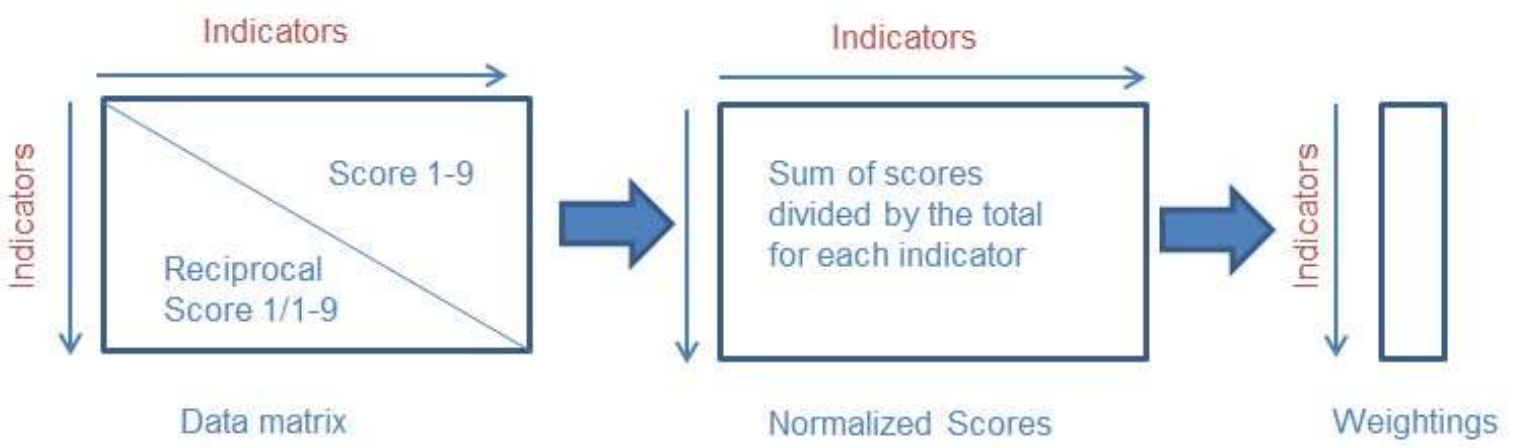

Figure 4. The analytical hierarchical process calculation for weighting parameters influencing methane output.

\begin{tabular}{|c|c|c|c|c|c|c|}
\hline Cell Name & & 1 & 2 & 3 & 4 & 5 \\
\hline \multicolumn{7}{|c|}{ Methane Output Score (\%) } \\
\hline & Methane Output $\theta$ & $44.8 \% \Theta$ & $60.9 \% \bigcirc$ & $-7.2 \% \bigcirc$ & $-57.7 \% @$ & $-57.5 \%$ \\
\hline \multicolumn{7}{|c|}{ Landfill Gas Indicator Scores } \\
\hline & Moisture Content $\bigcirc$ & -0.10 & 0.40 & 1.00 & 1.60 & -1.9 \\
\hline & Alkalinity as $\mathrm{CaCO}_{2} \mathrm{O}$ & 1.00 & 0.00 & 3.00 & 1.00 & -4.0 \\
\hline & $\underline{\mathrm{pH}} \mathrm{O}$ & $-1.4 \bigcirc$ & $-0.2 \#$ & 0 & -2.50 & -1.0 \\
\hline & BOD/COD ratio $O$ & 0.20 & -0.20 & -0.10 & -0.30 & 0.1 \\
\hline & COD $O$ & $1.5 \bigcirc$ & 0.00 & 1.00 & -0.50 & 1.0 \\
\hline & BOD 5 dav 0 & 0.00 & $0.0 \#$ & 0 & $0.1 \#$ & \\
\hline & Temperature 0 & 0.00 & 0.00 & 2.00 & -2.00 & -2.0 \\
\hline & $\underline{\text { Zinc }} \bigcirc$ & -0.30 & -0.20 & -0.30 & $-0.2 \#$ & \\
\hline & Iron 0 & 0.00 & $0.0 \#$ & 0 & -0.10 & 0.0 \\
\hline & Chloride $\bigcirc$ & $-0.5 \#$ & 0 & 0.40 & 0.90 & -0.1 \\
\hline & Ammonia - $\mathrm{N} O$ & 0.00 & 0.00 & 0.10 & 0.10 & 0.2 \\
\hline & core (weighted and absolute) $\bigcirc$ & 0.60 & 0.20 & 1.10 & 1.20 & 1.6 \\
\hline
\end{tabular}

Figure 5. DST results display including the lights for each score. 
Table 1. DST Leachate dataset tab showing typical leachate composition upper and lower boundary and average values in acetogenic and methanogenic conditions (Ehrig, 1983; Ehrig, 1988; Tchobanoglous et al., 1993). All parameters in mg/L unless otherwise stated.

\begin{tabular}{|c|c|c|c|c|c|c|}
\hline \multirow[b]{2}{*}{ Indicator } & \multicolumn{3}{|c|}{ Methanogenesis } & \multicolumn{3}{|c|}{ Acetogenesis } \\
\hline & Lower & Average & Upper & Lower & Average & Upper \\
\hline $\begin{array}{l}\text { Moisture Content } \\
(\%)\end{array}$ & 42.5 & 25 & 60 & & & \\
\hline Temperature $\left({ }^{\circ} \mathbf{C}\right)$ & 30 & 20 & 40 & & & \\
\hline pH & 4.5 & 6.1 & 7.5 & 7.5 & 8 & 9 \\
\hline $\begin{array}{l}\text { Alkalinity as } \\
\mathrm{CaCO}_{3}\end{array}$ & 1000 & 5000 & 10,000 & 500 & 600 & 700 \\
\hline BOD5 & 4000 & 13000 & 40,000 & 20 & 180 & 550 \\
\hline COD & 6000 & 22000 & 60,000 & 500 & 3000 & 4500 \\
\hline BOD/COD Ratio & - & 0.58 & - & - & 0.06 & - \\
\hline Sulfate & 70 & 500 & 1750 & 10 & 80 & 420 \\
\hline Calcium & 10 & 1200 & 25,000 & 20 & 60 & 600 \\
\hline Magnesium & 50 & 470 & 1150 & 40 & 180 & 350 \\
\hline Iron & 20 & 780 & 2100 & 3 & 15 & 280 \\
\hline Manganese & 0.3 & 25 & 65 & 0.03 & 0.7 & 45 \\
\hline Ammonia -N & & & & 50 & 740 & 2200 \\
\hline Chloride & & & & 150 & 2120 & 4500 \\
\hline Potassium & & & & & 1085 & \\
\hline Sodium & & & & & 1340 & \\
\hline Phosphorous & & & & & 6 & \\
\hline Cadmium & & & & & 0.005 & \\
\hline Chromium & & & & & 0.28 & \\
\hline Cobalt & & & & & 0.05 & \\
\hline Copper & & & & & 0.065 & \\
\hline Lead & & & & & 0.09 & \\
\hline Nickel & & & & & 0.17 & \\
\hline Zinc & 0.1 & 5 & 120 & 0.03 & 0.6 & 4 \\
\hline
\end{tabular}


Table 2. A description of the traffic light system for individual and total landfill gas indicator scores. Boundary levels are set by the ideal range for each indicator.

\begin{tabular}{|c|c|c|}
\hline Traffic Light & Score Boundary & Description \\
\hline Green & Between -1 and 1 . & $\begin{array}{l}\text { Indicator is within accepted } \\
\text { range for good methane } \\
\text { production. }\end{array}$ \\
\hline Yellow & $\begin{array}{l}\text { Between }-1.25 \text { and }-1 \text { and } \\
\text { between } 1 \text { and } 1.25 \text {. }\end{array}$ & $\begin{array}{l}\text { Indicator is outside the } \\
\text { accepted range and close } \\
\text { monitoring is necessary. }\end{array}$ \\
\hline Red & $\begin{array}{l}\text { Greater than }-1.25 \text { and } \\
\text { greater than } 1.25 \text {. }\end{array}$ & $\begin{array}{l}\text { Indicator is well outside the } \\
\text { accepted range and } \\
\text { remedial action is } \\
\text { necessary. }\end{array}$ \\
\hline
\end{tabular}


Table 3. The AHP process for calculating the default weights for the landfill gas indicators. The first stage is to make pairwise comparisons for each indicator assigning a score of 1-9. The reciprocal score is used for the reciprocal pairwise comparison. The AHP normalization process for calculating the default weights for the landfill gas indicators are shown in brackets.

\begin{tabular}{|c|c|c|c|c|c|c|c|c|c|c|c|c|}
\hline & 窇 & 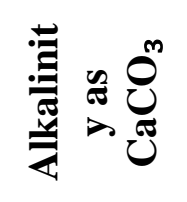 & 폴 & 它 & ○ิ & $\hat{\theta}_{n}^{n} \vec{\theta}$ & 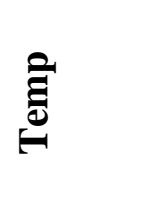 & $\stackrel{\mathscr{N}}{*}$ & อี & 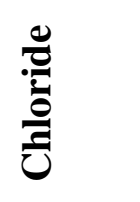 & 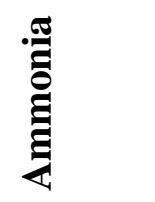 & م0 \\
\hline Moisture Content & $\begin{array}{c}1 \\
(0.32)\end{array}$ & $\begin{array}{c}2 \\
(0.42)\end{array}$ & $\begin{array}{c}3 \\
(0.35)\end{array}$ & $\begin{array}{c}4 \\
(0.29)\end{array}$ & $\begin{array}{c}5 \\
(0.25)\end{array}$ & $\begin{array}{c}5 \\
(0.24)\end{array}$ & $\begin{array}{c}6 \\
(0.21)\end{array}$ & $\begin{array}{c}9 \\
(0.18)\end{array}$ & $\begin{array}{c}9 \\
(0.18)\end{array}$ & $\begin{array}{c}9 \\
(0.18)\end{array}$ & $\begin{array}{c}9 \\
(0.20)\end{array}$ & 0.26 \\
\hline $\begin{array}{l}\text { Alkalinity as } \\
\mathrm{CaCO}_{3}\end{array}$ & $0.5(0.16)$ & $\begin{array}{c}1 \\
(0.21)\end{array}$ & $\begin{array}{c}3 \\
(0.35)\end{array}$ & $\begin{array}{c}4 \\
(0.29)\end{array}$ & $\begin{array}{c}5 \\
(0.25)\end{array}$ & $\begin{array}{c}5 \\
(0.24)\end{array}$ & $\begin{array}{c}5 \\
(0.18)\end{array}$ & $\begin{array}{c}7 \\
(0.14)\end{array}$ & $\begin{array}{c}7 \\
(0.14)\end{array}$ & $\begin{array}{c}7 \\
(0.14)\end{array}$ & $\begin{array}{c}8 \\
(0.18)\end{array}$ & 0.21 \\
\hline pH & $\begin{array}{c}0.33 \\
(011)\end{array}$ & $\begin{array}{c}0.33 \\
(0.07)\end{array}$ & $\begin{array}{c}1 \\
(0.12)\end{array}$ & $\begin{array}{c}3 \\
(0.22)\end{array}$ & $\begin{array}{c}4 \\
(0.20)\end{array}$ & $\begin{array}{c}4 \\
(0.19)\end{array}$ & $\begin{array}{c}5 \\
(0.18)\end{array}$ & $\begin{array}{c}7 \\
(0.14)\end{array}$ & $\begin{array}{c}7 \\
(0.14)\end{array}$ & $\begin{array}{c}7 \\
(0.14)\end{array}$ & $8(0.18)$ & 0.15 \\
\hline BOD/COD ratio & $\begin{array}{c}0.25 \\
(0.08)\end{array}$ & $\begin{array}{c}0.25 \\
(0.05)\end{array}$ & $\begin{array}{c}0.33 \\
(0.04)\end{array}$ & $\begin{array}{c}1 \\
(0.07)\end{array}$ & $\begin{array}{c}3 \\
(0.15)\end{array}$ & $\begin{array}{c}3 \\
(0.14)\end{array}$ & $\begin{array}{c}4 \\
(0.14)\end{array}$ & $\begin{array}{c}6 \\
(0.12)\end{array}$ & $\begin{array}{c}6 \\
(0.12)\end{array}$ & $\begin{array}{c}6 \\
(0.12)\end{array}$ & $6(0.13)$ & 0.11 \\
\hline COD & $0.2(0.06)$ & $0.2(0.04)$ & $\begin{array}{c}0.25 \\
(0.03)\end{array}$ & $\begin{array}{c}0.33 \\
(0.02)\end{array}$ & $\begin{array}{c}1 \\
(0.05)\end{array}$ & $\begin{array}{c}2 \\
(0.09)\end{array}$ & $\begin{array}{c}3 \\
(0.11)\end{array}$ & $\begin{array}{c}5 \\
(0.10)\end{array}$ & $\begin{array}{c}5 \\
(0.10)\end{array}$ & $\begin{array}{c}5 \\
(0.10)\end{array}$ & $5(0.11)$ & 0.07 \\
\hline BOD & $0.2(0.06)$ & $0.2(0.04)$ & $\begin{array}{c}0.25 \\
(0.03)\end{array}$ & $\begin{array}{c}0.33 \\
(0.02)\end{array}$ & $0.5(0.03)$ & $\begin{array}{c}1 \\
(0.05)\end{array}$ & $\begin{array}{c}3 \\
(0.11)\end{array}$ & $\begin{array}{c}5 \\
(0.10)\end{array}$ & $\begin{array}{c}5 \\
(0.10)\end{array}$ & $\begin{array}{c}5 \\
(0.10)\end{array}$ & $5(0.11)$ & 0.07 \\
\hline Temperature & $\begin{array}{c}0.17 \\
(0.05)\end{array}$ & $0.2(0.04)$ & $0.2(0.02)$ & $\begin{array}{l}0.25 \\
(0.02)\end{array}$ & $\begin{array}{c}0.33 \\
(0.02)\end{array}$ & $\begin{array}{c}0.33 \\
(0.02)\end{array}$ & $\begin{array}{c}1 \\
(0.04)\end{array}$ & $\begin{array}{c}3 \\
(0.06)\end{array}$ & $\begin{array}{c}3 \\
(0.06)\end{array}$ & $\begin{array}{c}3 \\
(0.06)\end{array}$ & $3(0.07)$ & 0.04 \\
\hline Zinc & $\begin{array}{c}0.11 \\
(0.04)\end{array}$ & $\begin{array}{c}0.15 \\
(0.03)\end{array}$ & $\begin{array}{c}0.14 \\
(0.02)\end{array}$ & $\begin{array}{c}0.17 \\
(0.01)\end{array}$ & $0.2(0.01)$ & $0.2(0.01)$ & $\begin{array}{c}0.33 \\
(0.01)\end{array}$ & $\begin{array}{c}1 \\
(0.02)\end{array}$ & $\begin{array}{c}1 \\
(0.02)\end{array}$ & $\begin{array}{c}1 \\
(0.02)\end{array}$ & $\begin{array}{c}0.2 \\
(0.00)\end{array}$ & 0.02 \\
\hline Iron & $\begin{array}{c}0.11 \\
(0.04)\end{array}$ & $\begin{array}{c}0.15 \\
(0.03)\end{array}$ & $\begin{array}{c}0.14 \\
(0.02)\end{array}$ & $\begin{array}{c}0.17 \\
(0.01)\end{array}$ & $0.2(0.01)$ & $0.2(0.01)$ & $\begin{array}{c}0.33 \\
(0.01)\end{array}$ & $\begin{array}{c}1 \\
(0.02)\end{array}$ & $\begin{array}{c}1 \\
(0.02)\end{array}$ & $\begin{array}{c}1 \\
(0.02)\end{array}$ & $\begin{array}{c}0.2 \\
(0.00)\end{array}$ & 0.02 \\
\hline Chloride & $\begin{array}{c}0.11 \\
(0.04)\end{array}$ & $\begin{array}{c}0.14 \\
(0.03)\end{array}$ & $\begin{array}{c}0.14 \\
(0.02)\end{array}$ & $\begin{array}{c}0.17 \\
(0.01)\end{array}$ & $0.2(0.01)$ & $0.2(0.01)$ & $\begin{array}{c}0.33 \\
(0.01)\end{array}$ & $\begin{array}{c}1 \\
(0.02)\end{array}$ & $\begin{array}{c}1 \\
(0.02)\end{array}$ & $\begin{array}{c}1 \\
(0.02)\end{array}$ & $\begin{array}{c}0.17 \\
(0.00)\end{array}$ & 0.02 \\
\hline Ammonia & $\begin{array}{c}0.11 \\
(0.04)\end{array}$ & $\begin{array}{c}0.13 \\
(0.03)\end{array}$ & $\begin{array}{c}0.13 \\
(0.01)\end{array}$ & $\begin{array}{c}0.17 \\
(0.01)\end{array}$ & $0.2(0.01)$ & $0.2(0.01)$ & $\begin{array}{c}0.33 \\
(0.01)\end{array}$ & $\begin{array}{c}5 \\
(0.10)\end{array}$ & $\begin{array}{c}5 \\
(0.10)\end{array}$ & $\begin{array}{c}6 \\
(0.12)\end{array}$ & $1(0.02)$ & 0.04 \\
\hline TOTAL & 3.09 & 4.74 & 8.59 & 13.66 & 19.63 & 21.13 & 28.33 & 50 & 50 & 51 & 45.57 & \\
\hline
\end{tabular}


Table 4. Potential remedies given in the DST for parameters with red or yellow traffic light scores (adapted from Mali Sandip (2012), Mata-Alvarez (2003) and Christensen et al. (1996)).

\begin{tabular}{|c|c|c|c|}
\hline Indicator & Cause & Effect & Potential Remedies \\
\hline $\begin{array}{l}\text { Methane } \\
\text { output }\end{array}$ & $\begin{array}{l}\text { Potentially unknown if data for } \\
\text { environmental indicators is not } \\
\text { entered. }\end{array}$ & $\begin{array}{l}\text { Lower than predicted methane output today and } \\
\text { potentially in the future. }\end{array}$ & $\begin{array}{l}\text { A general improvement of landfill methane generation can be } \\
\text { sought by ensuring a mixed composition waste input in the absence } \\
\text { of toxic agents and pH neutral leachate recirculation to enhance } \\
\text { microbial activity. See below for more detailed remedial action for } \\
\text { individual indicators. }\end{array}$ \\
\hline $\begin{array}{l}\text { Waste } \\
\text { composition }\end{array}$ & Waste selection for landfill. & $\begin{array}{l}\text { Organic overload or lack of substrate for biogas } \\
\text { conversion. Imbalance of acetogenesis and } \\
\text { methanogenesis. Accumulation VFAs. }\end{array}$ & Mixture of waste types placed in landfills. \\
\hline $\begin{array}{l}\text { Density of } \\
\text { waste }\end{array}$ & Amount of waste, waste placement. & $\begin{array}{l}\text { Leachate pooling, waste saturation, poor nutrient } \\
\text { distribution. }\end{array}$ & $\begin{array}{l}\text { Pre-shredding of waste prior to landfill entry and the establishment } \\
\text { of maximum cell loads. }\end{array}$ \\
\hline $\begin{array}{l}\text { Moisture } \\
\text { content }\end{array}$ & $\begin{array}{l}\text { Rainfall, permeability, leachate } \\
\text { management engineering. }\end{array}$ & $\begin{array}{l}\text { Excessive moisture can cause a microorganisms washout, } \\
\text { reducing } \mathrm{pH} \text { and methane production. However there is } \\
\text { an exponential increase in gas between } 25-60 \% \text { moisture } \\
\text { content. Limits oxygen content. Facilitates exchange of } \\
\text { substrate, nutrients, buffer and microorganisms to prevent } \\
\text { the build-up of VFAs and hydrogen. }\end{array}$ & $\mathrm{pH}$ neutral leachate recirculation to prevent stagnation or saturation. \\
\hline pH/ alkalinity & Volatile fatty acids (VFA) build up. & $\begin{array}{l}\text { Imbalance of acetogenesis and methanogenesis. } \\
\text { Accumulation of volatile fatty acids due to the inability } \\
\text { of methanogens to convert them to methane causes a fall } \\
\text { in pH. }\end{array}$ & $\begin{array}{l}\text { High alkalinity/pH: Addition of sodium bicarbonate/ calcium } \\
\text { carbonate buffer to leachate for recirculation to achieve the optimum } \\
\text { range for methanogen bacteria (around } \mathrm{pH} 7 \text { ). Waste could also be } \\
\text { pre-composted aerobically to skip the acetogenesis stage. }\end{array}$ \\
\hline $\begin{array}{l}\text { BOD/COD } \\
\text { ratio }\end{array}$ & $\begin{array}{l}\text { Lack of biodegradable substrate or } \\
\text { an inhibited biodegradation } \\
\text { process. (Ratio of biologically } \\
\text { degradable to chemically } \\
\text { oxidisable substrate. Reflects the } \\
\text { degradability of organic carbon.) }\end{array}$ & $\begin{array}{l}\text { Lower than predicted methane output today and } \\
\text { potentially in the future. }\end{array}$ & $\begin{array}{l}\text { Adjust waste input or consider alternative parameters for } \\
\text { methanogenesis inhibition. } \\
\text { Microbial seeding from sewage/ AD sludge. Introduction of gravel } \\
\text { to increase surface area for microbial growth. }\end{array}$ \\
\hline Temperature & $\begin{array}{l}\text { Environmental conditions, leachate } \\
\text { recirculation or air suction. }\end{array}$ & $\begin{array}{l}\text { Methane yield increases with temperature. Temperature } \\
\text { increases methane x } 100 \text { by } 20-30 \text { degrees and } 30-40 \\
\text { decrease. Self-enhancing. }\end{array}$ & Pre heat leachate or prevent aeration. \\
\hline $\mathrm{Fe}, \mathrm{Zn}, \mathrm{Cl}$ & $\begin{array}{l}\text { Presence of toxic agents/inhibitors } \\
\text { including heavy metals, solvents, } \\
\text { high levels of hydrogen, ammonia, } \\
\text { sulphides. }\end{array}$ & $\begin{array}{l}\text { Microbial inhibition. Imbalance of aceotgenesis and } \\
\text { methanogenesis. Accumulation VFAs }\end{array}$ & $\begin{array}{l}\text { Landfill dynamic equilibrium has the ability to regulate inhibitors } \\
\text { naturally. Pre-screening of waste input or cell isolation to prevent } \\
\text { dispersal. Iron present in waste acts as a sulphide sink. }\end{array}$ \\
\hline Ammonia & Waste composition & High ammonia levels increases $\mathrm{pH}$. & Adjust waste input. \\
\hline
\end{tabular}


Table 5. Waste acceptance, gas, leachate and waste data for five example landfill sites

\begin{tabular}{|c|c|c|c|c|c|}
\hline Site Number & 1 & 2 & 3 & 4 & 5 \\
\hline \multicolumn{6}{|l|}{ Waste Input } \\
\hline Landfill Open Year* & 1986 & 1998 & 2005 & 1992 & 1989 \\
\hline Closure Year & 2009 & & & & 2006 \\
\hline Year of Analysis* & 2012 & 2012 & 2012 & 2012 & 2012 \\
\hline Age of site at year of analysis (years) & 26 & 14 & 7 & 20 & 23 \\
\hline \multicolumn{6}{|l|}{ Accepted Waste Mass ('000 tonnes)* } \\
\hline \multicolumn{6}{|l|}{ Year } \\
\hline 0 & 200 & 50 & 150 & 10 & 100 \\
\hline 1 & 200 & 20 & 150 & 20 & 100 \\
\hline 2 & 200 & 30 & 150 & 30 & 100 \\
\hline 3 & 200 & 100 & 150 & 40 & 100 \\
\hline 4 & 200 & 90 & 150 & 50 & 100 \\
\hline 5 & 200 & 106 & 150 & 60 & 100 \\
\hline 6 & 200 & 122 & 150 & 70 & 100 \\
\hline 7 & 200 & 138 & 150 & 80 & 100 \\
\hline 8 & 200 & 154 & 150 & 90 & 100 \\
\hline 9 & 200 & 170 & 150 & 100 & 100 \\
\hline 10 & 200 & 186 & 150 & 110 & 100 \\
\hline 11 & 200 & 202 & 150 & 120 & 100 \\
\hline 12 & 200 & 218 & 150 & 130 & 100 \\
\hline 13 & 200 & 234 & 150 & 140 & 100 \\
\hline 14 & 200 & 250 & 150 & 150 & 100 \\
\hline 15 & 200 & 266 & 150 & 160 & 100 \\
\hline 16 & 200 & 282 & 150 & 170 & 100 \\
\hline 17 & 200 & 298 & 150 & 180 & \\
\hline 18 & 200 & 314 & 150 & 190 & \\
\hline 19 & 200 & 330 & & 200 & \\
\hline 20 & 200 & 346 & & 210 & \\
\hline 21 & 200 & 362 & & 220 & \\
\hline 22 & 200 & 378 & & 230 & \\
\hline 23 & 200 & 394 & & 240 & \\
\hline 24 & & 410 & & 250 & \\
\hline 25 & & 426 & & 260 & \\
\hline 26 & & 442 & & 270 & \\
\hline 27 & & 458 & & 280 & \\
\hline 28 & & 474 & & 290 & \\
\hline 29 & & & & 300 & \\
\hline 30 & & & & 310 & \\
\hline \multicolumn{6}{|l|}{ Landfill Gas } \\
\hline $\begin{array}{l}\text { Total Landfill Gas Output } \\
\left(10^{6} \mathrm{~m}^{3} / \mathrm{yr}\right)^{*}\end{array}$ & 30 & 20 & 5 & 5 & 3 \\
\hline Methane Content (\%) & & 44 & 54 & & \\
\hline Methane Output $\left(10^{6} \mathrm{~m}^{3} / \mathrm{yr}\right)$ & 125 & 8.8 & 2.7 & 2.5 & 1.5 \\
\hline \multicolumn{6}{|l|}{ Waste Characteristics } \\
\hline Potential Methane Generation Capacity $\left(\mathrm{m}^{3} / \mathrm{Mg}\right)^{*}$ & 100 & 100 & 100 & 100 & 100 \\
\hline Moisture Content $(\%)$ & 40 & 50 & 60 & 70 & 10 \\
\hline Temperature $\left({ }^{\circ} \mathrm{C}\right)$ & 30 & 30 & 50 & 10 & 10 \\
\hline Leachate & & & & & \\
\hline
\end{tabular}




\begin{tabular}{lccccc}
\hline $\mathrm{pH}$ & 7.2 & 8.1 & $\#$ & 6.4 & 7.5 \\
$\mathrm{COD}(\mathrm{mg} / \mathrm{L})$ & 6,000 & 3,000 & 5,000 & 2,000 & 5,000 \\
BOD 5 day $(\mathrm{mg} / \mathrm{L})$ & 180 & 180 & $\#$ & 200 & $\#$ \\
BOD/COD ratio & 0.08 & 0.04 & 0.05 & 0.03 & 0.07 \\
Alkalinity as $\mathrm{CaCO}_{3}(\mathrm{mg} / \mathrm{L})$ & 700 & 600 & 900 & 700 & 100 \\
Chloride $(\mathrm{mg} / \mathrm{L})$ & 1000 & & 3000 & 4000 & 2000 \\
Ammonia-N $(\mathrm{mg} / \mathrm{L})$ & 750 & 700 & 800 & 900 & 1000 \\
Iron $(\mathrm{mg} / \mathrm{L})$ & 17 & 11 & $\#$ & 1 & 18 \\
Zinc $(\mathrm{mg} / \mathrm{L})$ & 0.1 & 0.2 & 0.1 & 0.3 & $\#$ \\
\hline
\end{tabular}

Table 6. The calculation of the DST results for site 1 .

\begin{tabular}{|c|c|c|c|c|c|c|}
\hline Parameter & $\begin{array}{c}\text { Ideal } \\
\text { Average }\end{array}$ & $\begin{array}{l}\text { Ideal } \\
\text { Range }\end{array}$ & Actual & $\begin{array}{l}\text { Deviation from } \\
\text { Ideal Average }\end{array}$ & $\mathbf{W}$ & $\mathbf{S}$ \\
\hline \multicolumn{7}{|l|}{ Landfill Gas } \\
\hline $\begin{array}{l}\text { Methane Output } \\
\left(\mathrm{m}^{3} / \mathrm{yr}\right)\end{array}$ & $10,356,453$ & - & $15,000,000$ & $44.8 \%$ & - & $\begin{array}{r}44.8 \\
\%\end{array}$ \\
\hline \multicolumn{7}{|l|}{$\begin{array}{l}\text { Landfill Gas } \\
\text { Indicators }\end{array}$} \\
\hline $\begin{array}{l}\text { Moisture Content } \\
(\%)\end{array}$ & 43 & 35 & 40 & -0.1 & 0.26 & 0.0 \\
\hline $\begin{array}{l}\text { Alkalinity as } \\
\mathrm{CaCO}_{3}(\mathrm{mg} / \mathrm{L})\end{array}$ & 600 & 200 & 700 & 1.0 & 0.21 & 0.2 \\
\hline $\mathrm{pH}$ & 8 & 2 & 7 & -1.4 & 0.15 & 0.2 \\
\hline $\mathrm{BOD} / \mathrm{COD}$ ratio & 0.06 & 0.20 & 0.08 & 0.2 & 0.11 & 0.0 \\
\hline COD (mg/L) & 3,000 & 4,000 & 6,000 & 1.5 & 0.07 & 0.1 \\
\hline BOD 5 day $(\mathrm{mg} / \mathrm{L})$ & 180 & 530 & 180 & 0.0 & 0.07 & 0.0 \\
\hline Temperature $\left({ }^{\circ} \mathrm{C}\right)$ & 30 & 20 & 30 & 0.0 & 0.04 & 0.0 \\
\hline Zinc (mg/L) & 1 & 4 & 0 & -0.3 & 0.02 & 0.0 \\
\hline Iron $(\mathrm{mg} / \mathrm{L})$ & 15 & 277 & 17 & 0.0 & 0.02 & 0.0 \\
\hline Chloride (mg/L) & 2,120 & 4,350 & 1,000 & -0.5 & 0.02 & 0.0 \\
\hline $\begin{array}{l}\text { Ammonia - N } \\
(\mathrm{mg} / \mathrm{L})\end{array}$ & 740 & 2,150 & 750 & 0.0 & 0.04 & 0.0 \\
\hline \multicolumn{6}{|c|}{ Total Indicator Score (absolute and weighted) } & 0.6 \\
\hline
\end{tabular}

W: weight; S: score. 
Table 7. The calculation of the DST results for site 2.

\begin{tabular}{|c|c|c|c|c|c|c|}
\hline Parameter & $\begin{array}{c}\text { Ideal } \\
\text { Average }\end{array}$ & $\begin{array}{l}\text { Ideal } \\
\text { Range }\end{array}$ & Actual & $\begin{array}{l}\text { Deviation from } \\
\text { Ideal Average }\end{array}$ & $\mathbf{W}$ & $\mathbf{S}$ \\
\hline \multicolumn{7}{|l|}{ Landfill Gas } \\
\hline $\begin{array}{l}\text { Methane Output } \\
\left(\mathrm{m}^{3} / \mathrm{yr}\right)\end{array}$ & $5,470,453$ & - & $\begin{array}{r}8,800 \\
000\end{array}$ & $60.9 \%$ & & $\begin{array}{r}60.9 \\
\%\end{array}$ \\
\hline \multicolumn{7}{|c|}{ Landfill Gas Indicators } \\
\hline $\begin{array}{l}\text { Moisture Content } \\
(\%)\end{array}$ & 43 & 35 & 50 & 0.4 & 0.26 & 0.1 \\
\hline $\begin{array}{l}\text { Alkalinity as } \mathrm{CaCO}_{3} \\
(\mathrm{mg} / \mathrm{L})\end{array}$ & 600 & 200 & 600 & 0.0 & 0.21 & 0.0 \\
\hline $\mathrm{pH}$ & 8 & 2 & 8 & -0.2 & 0.15 & 0.0 \\
\hline $\mathrm{BOD} / \mathrm{COD}$ ratio & 0.06 & 0.20 & 0.04 & -0.2 & 0.11 & 0.0 \\
\hline $\mathrm{COD}(\mathrm{mg} / \mathrm{L})$ & 3,000 & 4,000 & 3,000 & 0.0 & 0.07 & 0.0 \\
\hline BOD 5 day (mg/L) & 180 & 530 & 180 & 0.0 & 0.07 & 0.0 \\
\hline Temperature $\left({ }^{\circ} \mathrm{C}\right)$ & 30 & 20 & 30 & 0.0 & 0.04 & 0.0 \\
\hline Zinc (mg/L) & 1 & 4 & 0 & -0.2 & 0.02 & 0.0 \\
\hline Iron $(\mathrm{mg} / \mathrm{L})$ & 15 & 277 & 11 & 0.0 & 0.02 & 0.0 \\
\hline Chloride (mg/L) & 2,120 & 4,350 & 0 & 0.0 & 0.02 & 0.0 \\
\hline $\begin{array}{l}\text { Ammonia - N } \\
(\mathrm{mg} / \mathrm{L})\end{array}$ & 740 & 2,150 & 700 & 0.0 & 0.04 & 0.0 \\
\hline \multicolumn{6}{|c|}{ Total Indicator Score (absolute and weighted) } & 0.2 \\
\hline
\end{tabular}

W: weight; S: score.

Table 8. The calculation of the DST results for site 3 .

\begin{tabular}{lrrrrrr}
\hline \multicolumn{1}{c}{ Parameter } & $\begin{array}{c}\text { Ideal } \\
\text { Average }\end{array}$ & $\begin{array}{c}\text { Ideal } \\
\text { Range }\end{array}$ & Actual & $\begin{array}{c}\text { Deviation from } \\
\text { Ideal Average }\end{array}$ & W & S \\
\hline Landfill Gas & & & & & \\
Methane Output \\
$\left(\mathrm{m}^{3 / y r}\right.$ )
\end{tabular}

W: weight; S: score. 
Table 9. The calculation of the DST results for site 4 .

\begin{tabular}{|c|c|c|c|c|c|c|}
\hline Parameter & $\begin{array}{c}\text { Ideal } \\
\text { Average }\end{array}$ & $\begin{array}{l}\text { Ideal } \\
\text { Range }\end{array}$ & Actual & $\begin{array}{c}\text { Deviation } \\
\text { from Ideal } \\
\text { Average } \\
\end{array}$ & $\mathbf{W}$ & $\mathbf{S}$ \\
\hline \multicolumn{7}{|l|}{ Landfill Gas } \\
\hline $\begin{array}{l}\text { Methane Output } \\
\left(\mathrm{m}^{3} / \mathrm{yr}\right)\end{array}$ & $5,914,614$ & & $2,500,000$ & $-57.7 \%$ & & $\begin{array}{r}- \\
57.7 \\
\%\end{array}$ \\
\hline \multicolumn{7}{|l|}{ Landfill Indicators } \\
\hline $\begin{array}{l}\text { Moisture Content } \\
(\%)\end{array}$ & 43 & 35 & 70 & 1.6 & 0.26 & 0.4 \\
\hline $\begin{array}{l}\text { Alkalinity as } \mathrm{CaCO}_{3} \\
(\mathrm{mg} / \mathrm{L})\end{array}$ & 600 & 200 & 700 & 1.0 & 0.21 & 0.2 \\
\hline $\mathrm{pH}$ & 8 & 2 & 6 & -2.5 & 0.15 & -0.4 \\
\hline BOD/COD ratio & 0.06 & 0.20 & 0.03 & -0.3 & 0.11 & 0.0 \\
\hline COD (mg/L) & 3,000 & 4,000 & 2,000 & -0.5 & 0.07 & 0.0 \\
\hline BOD 5 day (mg/L) & 180 & 530 & 200 & 0.1 & 0.07 & 0.0 \\
\hline Temperature $\left({ }^{\circ} \mathrm{C}\right)$ & 30 & 20 & 10 & -2.0 & 0.04 & -0.1 \\
\hline Zinc (mg/L) & 1 & 4 & 0 & -0.2 & 0.02 & 0.0 \\
\hline Iron $(\mathrm{mg} / \mathrm{L})$ & 15 & 277 & 1 & -0.1 & 0.02 & 0.0 \\
\hline Chloride (mg/L) & 2,120 & 4,350 & 4,000 & 0.9 & 0.02 & 0.0 \\
\hline $\begin{array}{l}\text { Ammonia - N } \\
(\mathrm{mg} / \mathrm{L})\end{array}$ & 740 & 2,150 & 900 & 0.1 & 0.04 & 0.0 \\
\hline \multicolumn{6}{|c|}{ Total Indicator Score (absolute and weighted) } & 1.2 \\
\hline
\end{tabular}

W: weight; S: score.

Table 10. The calculation of the DST results for site 5.

\begin{tabular}{|c|c|c|c|c|c|c|}
\hline Parameter & $\begin{array}{c}\text { Ideal } \\
\text { Average }\end{array}$ & $\begin{array}{l}\text { Ideal } \\
\text { Range }\end{array}$ & Actual & $\begin{array}{l}\text { Deviation from } \\
\text { Ideal Average }\end{array}$ & $\mathbf{W}$ & $\mathbf{S}$ \\
\hline \multicolumn{7}{|l|}{ Landfill Gas } \\
\hline $\begin{array}{l}\text { Methane Output } \\
\left(\mathrm{m}^{3} / \mathrm{yr}\right)\end{array}$ & $3,527,910$ & & $1,500,000$ & $-57.48 \%$ & & $\begin{array}{r}- \\
57.5 \\
\%\end{array}$ \\
\hline \multicolumn{7}{|c|}{ Landfill Gas Indicators } \\
\hline $\begin{array}{l}\text { Moisture Content } \\
(\%)\end{array}$ & 43 & 35 & 10 & -1.9 & 0.26 & -0.5 \\
\hline $\begin{array}{l}\text { Alkalinity as } \mathrm{CaCO}_{3} \\
(\mathrm{mg} / \mathrm{L})\end{array}$ & 600 & 200 & 200 & -4.0 & 0.21 & -0.8 \\
\hline $\mathrm{pH}$ & 8 & 2 & 8 & -1.0 & 0.15 & -0.2 \\
\hline $\mathrm{BOD} / \mathrm{COD}$ ratio & 0.06 & 0.20 & 0.07 & 0.1 & 0.11 & 0.0 \\
\hline $\mathrm{COD}(\mathrm{mg} / \mathrm{L})$ & 3,000 & 4,000 & 5,000 & 1.0 & 0.07 & 0.1 \\
\hline BOD 5 day (mg/L) & 180 & 530 & 0 & 0.0 & 0.07 & 0.0 \\
\hline Temperature $\left({ }^{\circ} \mathrm{C}\right)$ & 30 & 20 & 10 & -2.0 & 0.04 & -0.1 \\
\hline Zinc (mg/L) & 1 & 4 & 0 & 0.0 & 0.02 & 0.0 \\
\hline Iron (mg/L) & 15 & 277 & 18 & 0.0 & 0.02 & 0.0 \\
\hline Chloride (mg/L) & 2,120 & 4,350 & 2,000 & -0.1 & 0.02 & 0.0 \\
\hline $\begin{array}{l}\text { Ammonia - N } \\
(\mathrm{mg} / \mathrm{L})\end{array}$ & 740 & 2,150 & 1,000 & 0.2 & 0.04 & 0.0 \\
\hline \multicolumn{6}{|c|}{ Total Indicator Score (absolute and weighted) } & 1.6 \\
\hline
\end{tabular}

W: weight; S: score. 